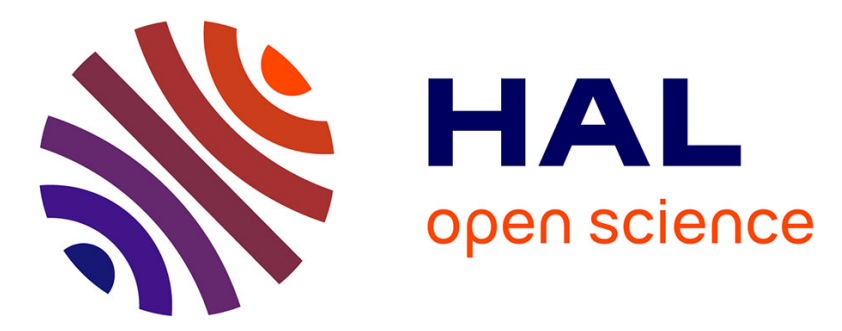

\title{
Kinetic Insight into the Electrochemical Lithium Insertion Process in the Puckered-Layer $\gamma^{\prime}$-V2O5 Polymorph
}

Rita Baddour-Hadjean, Marianne Safrany Renard, Jean Pierre Pereira-Ramos

\section{- To cite this version:}

Rita Baddour-Hadjean, Marianne Safrany Renard, Jean Pierre Pereira-Ramos. Kinetic Insight into the Electrochemical Lithium Insertion Process in the Puckered-Layer $\gamma$ '-V2O5 Polymorph. Journal of The Electrochemical Society, 2019, 166 (14), pp.A3474. 10.1149/2.1211914jes . hal-02335971

\section{HAL Id: hal-02335971 \\ https://hal.science/hal-02335971}

Submitted on 6 Nov 2020

HAL is a multi-disciplinary open access archive for the deposit and dissemination of scientific research documents, whether they are published or not. The documents may come from teaching and research institutions in France or abroad, or from public or private research centers.
L'archive ouverte pluridisciplinaire HAL, est destinée au dépôt et à la diffusion de documents scientifiques de niveau recherche, publiés ou non, émanant des établissements d'enseignement et de recherche français ou étrangers, des laboratoires publics ou privés. 
$1 \quad$ Kinetic insight into the electrochemical lithium insertion process in the puckered-layer $\gamma^{\prime}-\mathrm{V}_{2} \mathrm{O}_{5}$ polymorph

\begin{abstract}
Cycling properties, rate capability performance and kinetic parameters for $\mathrm{Li}$ insertion in the puckered $\gamma^{\prime}-\mathrm{V}_{2} \mathrm{O}_{5}$ host lattice are reported here in the $4.0 \mathrm{~V}-2.5 \mathrm{~V}$ voltage window corresponding to $0 \leq \mathrm{x} \leq 1$ in $\gamma-\mathrm{Li}_{\mathrm{x}} \mathrm{V}_{2} \mathrm{O}_{5}$. Whereas a high reversible behaviour and good cycling performance are achieved (135 $\mathrm{mAh} \mathrm{g}^{-1}$ after 50 cycles at $\left.\mathrm{C} / 10\right)$, the rate capability study shows a rapid increase in the discharge-charge hysteresis with the current density, impeding the recovering of high capacity values even at $\mathrm{C} / 2$ rate. The kinetics of the electrochemical lithium insertion reaction in $\gamma^{\prime}-\mathrm{V}_{2} \mathrm{O}_{5}$ has been investigated by ac impedance spectroscopy and discussed in the light of the structural mechanism. The chemical diffusion coefficient $\mathrm{D}_{\mathrm{Li}}$ is found constant in the $0 \leq \mathrm{x}<0.4$ biphasic region while lithium ions more rapidly diffuse in the solid solution domain $0.4 \leq \mathrm{x} \leq 1$ with greater $\mathrm{D}_{\mathrm{Li}}$ values by one or two orders of magnitude (around $10^{-9} \mathrm{~cm}^{2} \mathrm{~s}^{-1}$ ). An increase in charge transfer resistance and cathode impedance characterizes nevertheless the second part of the discharge. These findings explain the limitations in the reaction kinetics in the micrometric $\gamma^{\prime}-\mathrm{V}_{2} \mathrm{O}_{5}$ cathode material and give directions toward improved performance.
\end{abstract}

Keywords: $\gamma^{\prime}-\mathrm{V}_{2} \mathrm{O}_{5}$, cathode material, kinetics, Li diffusion, AC impedance spectroscopy 


\section{Introduction}

The $\alpha-\mathrm{V}_{2} \mathrm{O}_{5}$ polymorph was among the first transition metal oxide identified as $\mathrm{Li}$ intercalation compounds [1]. Its interest stems from a layered structure made of $\mathrm{V}_{2} \mathrm{O}_{5}$ sheets with Van der Waals interactions between oxide planes promoting facile insertion reactions. In addition, the presence of $2 \mathrm{~V}^{5+}$ ions allows a high capacity to be reached, i. e. $\approx 150 \mathrm{mAh} \mathrm{g}^{-1}$ and $300 \mathrm{mAh} \mathrm{g}^{-1}$ obtained for $0<\mathrm{x} \leq 1(3.5 \mathrm{~V}-2.5 \mathrm{~V}$ potential window $)$ and $0<\mathrm{x} \leq 2(3.5 \mathrm{~V}$ - $2.3 \mathrm{~V}$ potential window), respectively. Quite logically its possible application as cathode material in secondary Li batteries and Li-ion batteries prompted many researchers to work on the electrochemical properties of $\alpha-\mathrm{V}_{2} \mathrm{O}_{5}$ [1-10] with a special focus on the associate structural behaviour [4, 6-18]. Some results emerging from these works have allowed to establish the $\mathrm{Li}_{\mathrm{x}} \mathrm{V}_{2} \mathrm{O}_{5}$ phase diagram with $0<\mathrm{x}<2$ in which the successive emergence of more or less distorted lithiated phases is described $[2,4,7-9,18]$. In addition, the Li transport kinetics in this canonical intercalation host lattice has been deeply investigated as a function of $\mathrm{x}$ in $\mathrm{Li}_{\mathrm{x}} \mathrm{V}_{2} \mathrm{O}_{5}[19-25]$.

Recent studies based on DFT calculations have outlined the interest of metastable phases obtained from topochemical removal of cations from the appropriate $\mathrm{M}_{\mathrm{x}} \mathrm{V}_{2} \mathrm{O}_{5}$ bronzes $(\mathrm{M}=$ $\mathrm{Li}, \mathrm{Cu}, \mathrm{Ag})[26,27]$. A higher open circuit voltage combined with lower diffusion barriers are predicted as specific features of such cation-free metastable phases. Among the $\mathrm{V}_{2} \mathrm{O}_{5}$ polymorphs, the $\gamma^{\prime}-\mathrm{V}_{2} \mathrm{O}_{5}$ has been firstly mentioned to coexist with $\alpha-\mathrm{V}_{2} \mathrm{O}_{5}$ after a dischargecharge cycle in the $3.8 \mathrm{~V}-2.15 \mathrm{~V}$ potential range [8, 28, 29]. This $\gamma^{\prime}-\mathrm{V}_{2} \mathrm{O}_{5}$ polymorph is indeed the charge product of the highly puckered $\gamma-\mathrm{LiV}_{2} \mathrm{O}_{5}$ phase irreversibly produced upon discharge at $2.3 \mathrm{~V}$. Its formation is responsible for a voltage enhancement of $\approx 0.2 \mathrm{~V}$ related to the presence of two additional voltage plateaus at $3.6 \mathrm{~V}$ and $3.5 \mathrm{~V}$ upon cycling [8]. However, even when the chemical synthesis of $\gamma^{\prime}-\mathrm{V}_{2} \mathrm{O}_{5}$ was early proposed [28], only its lithiated $\gamma-\mathrm{LiV}_{2} \mathrm{O}_{5}$ has been investigated as positive electrode material for $\mathrm{Li}$-ion batteries [2935]. Various synthesis ways of $\gamma-\mathrm{LiV}_{2} \mathrm{O}_{5}$ were used such as carbothermal reduction at $600^{\circ} \mathrm{C}$ [30], precipitation reaction [31], hydrothermal or solvothermal routes [32-34], sol-gel templating route [35] leading to controversial and scattered results especially in the large $4 \mathrm{~V}$ $2 \mathrm{~V}$ window.

Surprisingly, the interest in the $\gamma^{\prime}-\mathrm{V}_{2} \mathrm{O}_{5}$ polymorph toward insertion reactions has been firstly illustrated in the case of sodium insertion [36-39]. Indeed, sodium is reversibly accommodated in $\gamma^{\prime}-\mathrm{V}_{2} \mathrm{O}_{5}$ at a high working voltage of $3.3 \mathrm{~V}$ vs $\mathrm{Na}^{+} / \mathrm{Na}$, remarkably at the 
same energy level as lithium insertion [36]. The strong puckering of the oxide layers in $\gamma^{\prime}-$ $\mathrm{V}_{2} \mathrm{O}_{5}$ probably promotes insertion reactions compared to the $\alpha-\mathrm{V}_{2} \mathrm{O}_{5}$ form. It is one of the reasons for considering the $\gamma^{\prime}$-polymorph as an interesting candidate as cathode material for Li batteries.

The electrochemical and structural study of $\gamma^{\prime}-\mathrm{V}_{2} \mathrm{O}_{5}$ toward Li insertion has been very recently reported [40]. A detailed XRD and Raman spectroscopy study allowed to establish the complete phase diagram of the $\mathrm{Li} / \gamma^{\prime}-\mathrm{V}_{2} \mathrm{O}_{5}$ system in the widest $4.00 \mathrm{~V}-2.15 \mathrm{~V}$ voltage window. This pioneering work unveiled the interest of the corrugated $\gamma^{\prime}-\mathrm{V}_{2} \mathrm{O}_{5}$ framework to accommodate a large amount of $\mathrm{Li}$ ions (up to $2 \mathrm{Li} /$ mole of oxide). The typical discharge exhibits two pairs of well-defined reversible steps at 3.58/3.47 V and 2.42/2.36 V separated by a sharp potential drop of about $1 \mathrm{~V}$. A strong influence of the depth of discharge on the cycling performance was outlined [40]. In the widest $4.00 \mathrm{~V}-2.15 \mathrm{~V}$ voltage window $(0<\mathrm{x} \leq$ 1.94), a high capacity of $285 \mathrm{mAh} \mathrm{g}^{-1}$ was reported. However, severe capacity fading upon cycling was observed in this voltage range due to the emergence of the fully lithiated $\zeta$ $\mathrm{Li}_{\approx 2} \mathrm{~V}_{2} \mathrm{O}_{5}$ phase at $2.36 \mathrm{~V}$. By reducing the voltage limits to $4.0 \mathrm{~V}-2.4 \mathrm{~V}$ region $(0<\mathrm{x} \leq 1.3)$, an attractive capacity of $185 \mathrm{mAh} \mathrm{g}^{-1}$ was reached, but still associated to a continuous capacity fading. Furthermore, the sharp potential drop of $1 \mathrm{~V}$ around $\mathrm{x}=1$ constitutes another important drawback in the $4.0 \mathrm{~V}-2.4 \mathrm{~V}$ voltage range.

The present paper focuses on the electrochemical properties of $\gamma^{\prime}-\mathrm{V}_{2} \mathrm{O}_{5}$ in the high voltage window corresponding to the exchange of $1 \mathrm{Li}^{+} /$mole of oxide $\left(147 \mathrm{mAh} \mathrm{g}^{-1}\right)$. Cycling properties, rate capability behaviour and kinetics parameters for $\mathrm{Li}$ insertion in $\gamma^{\prime}-\mathrm{V}_{2} \mathrm{O}_{5}$ are reported here in the $4.0 \mathrm{~V}-2.5 \mathrm{~V}$ voltage window. The kinetic data are discussed at the light of the structural mechanism recently evidenced for $\gamma^{\prime}-\mathrm{V}_{2} \mathrm{O}_{5}$.

\section{Experimental}

$\gamma^{\prime}-\mathrm{V}_{2} \mathrm{O}_{5}$ is obtained by chemical oxidation of $\gamma-\mathrm{LiV}_{2} \mathrm{O}_{5}$ synthesized by the carbothermal reduction method [30]. A solution of $\mathrm{NO}_{2} \mathrm{BF}_{4}$ (solid Alfa Aesar 96\%) in acetonitrile, molar ratio 1:4, allows the complete $\mathrm{Li}$ removal from the $\gamma-\mathrm{LiV}_{2} \mathrm{O}_{5}$ host structure. The solution is maintained under stirring at room temperature for $24 \mathrm{~h}$. After reaction and decantation, the supernatant liquid is removed by pipetting. After three successive washing steps with 
acetonitrile, the powder is then vacuum dried at $70^{\circ} \mathrm{C}$ for $24 \mathrm{~h}$. The powder color changing from black to orange confirms the complete lithium deintercalation. Electrochemical titration and chemical redox titration confirmed the 5+ oxidation state of vanadium in $\gamma^{\prime}-\mathrm{V}_{2} \mathrm{O}_{5}$. Two-electrode coin cells (CR 2032) with lithium disk as reference and auxiliary electrodes were used to perform electrochemical studies. $\gamma^{\prime}-\mathrm{V}_{2} \mathrm{O}_{5}$ positive electrode was prepared by mixing $80 \mathrm{wt} \%$ of active material, $7.5 \mathrm{wt} \%$ of acetylene black, $7.5 \mathrm{wt} \%$ of graphite and $5 \mathrm{wt} \%$ of teflon as binder agent. About $10 \mathrm{mg}$ of this mixture was pressed on a stainless steel grid (14 mm diam., $0.35 \mathrm{~mm}$ thick) under a pressure of 5 tons per $\mathrm{cm}^{2}$. The separator consists of three glass Whatman microfiber filters soaked by a solution of $1 \mathrm{M} \mathrm{LiClO}_{4}$ in propylene carbonate (PC) as electrolyte. All the coin cells were assembled in an argon-filled glove box where water and oxygen concentrations were kept less than $1 \mathrm{ppm}$. Electrochemical experiments were performed at ambient temperature using a VMP3 Biologic apparatus.

Impedance measurements were carried out in conventional three electrode cells under argon atmosphere. The cell was filled with $1 \mathrm{M} \mathrm{LiClO}_{4}$ in propylene carbonate (PC). The positive electrode was made of the active material in the same manner as the composite electrode used in coin cell for cycling and rate capability experiments. Reference and counter electrodes were made of $\mathrm{Li}$ wires in separate compartments filled up with electrolyte. The working electrode composition was changed by coulometric titration using a low current density corresponding to a $\mathrm{C} / 20$ rate. Equilibrium was considered as reached when the open circuit voltage remained stable $(<0.2 \mathrm{mV}$ for $1 \mathrm{~h})$. A discharge curve performed at very low rate $(\mathrm{C} / 100)$ is considered as the OCV curve. Impedance measurements were performed in the frequency range $4 \times 10^{4}$ to $0.5 \times 10^{-3} \mathrm{~Hz}$ with a VMP3 Biologic Multipotentiostat-Galvanostat apparatus. The excitation signal was $10 \mathrm{mV}$ peak to peak. All these electrochemical measurements were performed in an argon-filled glove box.

XRD measurements were performed using a Panalytical X'pert pro diffractometer equipped with an X'celerator detector and a Co K $\alpha$ radiation (wavelength $\lambda=1.7889 \AA$ ). 
The X-ray diffraction pattern of the $\gamma^{\prime}-\mathrm{V}_{2} \mathrm{O}_{5}$ powder is shown in Figure 1. All the diffraction lines can be indexed on the basis of an orthorhombic symmetry (space group Pnma) with the following unit cell parameters: $a=9.95 \AA ; b=3.59 \AA ; c=10.04 \AA$. These values are in good accord with those previously reported [28, 36-38]. The $\gamma^{\prime}-\mathrm{V}_{2} \mathrm{O}_{5}$ powder is characterized by a high $00 l$ preferred orientation corresponding to the stacking of platelets along the $c$ axis. SEM micrograph (see inset in Figure 1) indicates big aggregates made of platelets of a few $\mu \mathrm{m}$. The corresponding layered structure is composed of infinite ribbons parallel to the $b$ axis made of $\mathrm{VO}_{5}$ edges-sharing distorted pyramids alternatively up and down, as illustrated in Figure 2. These ribbons are linked to each other along the $a$ - direction by one corner's oxygen, leading to folded layers laying in the $(a b)$ plane and stacked along the $c$-axis.

A typical discharge curve performed at very low current density $(\mathrm{C} / 100)$ allows to get a quasiequilibrium voltage-composition curve $\mathrm{E}$ vs $\mathrm{x}$ in $\gamma-\mathrm{Li}_{\mathrm{x}} \mathrm{V}_{2} \mathrm{O}_{5}$ (Figure 3). From the very first lithium ions, the potential rapidly decreases from $4 \mathrm{~V}$ to $3.62 \mathrm{~V}$ and remains stable near $3.6 \mathrm{~V}$ in the $0.02<\mathrm{x}<0.4$ lithium composition range. Then, a potential decline from 3.6 to $3.55 \mathrm{~V}$ is observed for $0.4<\mathrm{x}<0.5$ followed by a less sloping decrease from $3.55 \mathrm{~V}$ to $3.45 \mathrm{~V}$ in the $0.5<\mathrm{x}<0.92$ composition range. For higher Li contents, a sharp potential drop up to $2.5 \mathrm{~V}$ leads to the full lithiation of $\gamma^{\prime}-\mathrm{V}_{2} \mathrm{O}_{5}$ into $\gamma-\mathrm{LiV}_{2} \mathrm{O}_{5}$. The maximum specific capacity delivered by $\gamma^{\prime}-\mathrm{V}_{2} \mathrm{O}_{5}$ in this voltage window reaches the value of $147 \mathrm{mAh} \mathrm{g}^{-1}$.

The discharge-charge curves of $\gamma^{\prime}-\mathrm{V}_{2} \mathrm{O}_{5}$ performed at $\mathrm{C} / 10$ exhibit a similar profile, consisting in two steps located at $3.58 \mathrm{~V}$ and $3.47 \mathrm{~V}$ (Figure 4). The first discharge process involves a specific capacity of $145 \mathrm{mAh} \mathrm{g}^{-1}$. Then, a quantitative charge process allows the extraction of 1 lithium ion from $\gamma-\mathrm{LiV}_{2} \mathrm{O}_{5}$ in two steps located at $3.65 \mathrm{~V}$ and $3.52 \mathrm{~V}$, leading to a symmetric charge-discharge profile. The cycling experiments (see inset in Figure 4) indicate a high reversible behaviour and a slow capacity decline limited to 6\% with still 135 $\mathrm{mAh} \mathrm{g}^{-1}$ recovered after 50 cycles. This behaviour competes well with the value of $125 \mathrm{mAh}$ $\mathrm{g}^{-1}$ reported at $\mathrm{C} / 5$ for $\gamma-\mathrm{LiV}_{2} \mathrm{O}_{5}$ prepared by the carbothermal reduction method [30] and outperforms the capacities of 100-110 $\mathrm{mAh} \mathrm{g}^{-1}$ and $57 \mathrm{mAh} \mathrm{g}^{-1}$ reported for $\gamma-\mathrm{LiV}_{2} \mathrm{O}_{5}$ prepared respectively by a precipitation technique [31] and a direct sol-gel soft templating method [35]. 
The influence of the $\mathrm{C}$ rate on the discharge-charge profile of $\gamma^{\prime}-\mathrm{V}_{2} \mathrm{O}_{5}$ is reported in Figure 5. At C/5 and C/10, similar capacities are achieved, i.e. 145 and $140 \mathrm{mAh} \mathrm{g}^{-1}$ respectively, and a value of still $130 \mathrm{mAh} \mathrm{g}^{-1}$ can be recovered at $\mathrm{C} / 2$. However, increasing the current density in the $\mathrm{C} / 2-5 \mathrm{C}$ range leads an increase in the polarization (Figure 5a). The hysteresis value of $200 \mathrm{mV}$ at C/2 greatly increases with higher current densities, which impedes the recovering of high efficiency when the $\mathrm{C}$ rate exceeds $1 \mathrm{C}$ : discharge capacities of 100,80 and $40 \mathrm{mAh} \mathrm{g}^{-}$ ${ }^{1}$ are obtained at C, $2 \mathrm{C}$ and $5 \mathrm{C}$ respectively (Figure 5b). These findings suggest some kinetic limitations occur and prompted us to examine in details the electrochemical kinetics of $\mathrm{Li}$ insertion into $\gamma^{\prime}-\mathrm{V}_{2} \mathrm{O}_{5}$.

The typical AC impedance diagrams obtained for $\gamma-\mathrm{Li}_{\mathrm{x}} \mathrm{V}_{2} \mathrm{O}_{5}$ electrodes are reported in Figure 6. The conventional equivalent circuit developed for intercalation compounds was used [41].Two kinds of Nyquist diagrams can be observed. For $0<x \leq 0.6$ (Figure 6a), all the spectra practically superimpose, showing a well-defined charge transfer semi-circle centered at $130-160 \mathrm{~Hz}$ followed by a straight line with a phase angle of $45^{\circ}$ up to $0.5 \mathrm{mHz}$ corresponding to the Warburg region (when $\omega \gg 2 \mathrm{D}_{\mathrm{Li}} / \mathrm{L}^{2}, \mathrm{~L}$ being the maximum length of the diffusion pathway) [41]. For higher $\mathrm{Li}$ contents, i.e. $0.6<\mathrm{x} \leq 1$, all the diagrams superimpose again but no reliable Warburg region can be defined (Figure 6b). Instead, the well-defined high frequency semi-circle is followed by a quasi-vertical line corresponding to the finite diffusion $\left(\omega<<2 \mathrm{D}_{\mathrm{Li}} / \mathrm{L}^{2}\right)$. This behaviour reveals a faster $\mathrm{Li}$ diffusion in the richest Li composition range. Another discrepancy concerns the lower value of the characteristic frequency of charge transfer, of $100 \mathrm{~Hz}$ in the $0.6<\mathrm{x} \leq 1$ composition range vs. $160-130 \mathrm{~Hz}$ for $0<x \leq 0.6$. Finally, the cathode impedance is significantly larger in the second half of the discharge.

The main kinetic parameters of the $\mathrm{Li}$ insertion reaction into $\gamma^{\prime}-\mathrm{V}_{2} \mathrm{O}_{5}$ like the cathode impedance $|Z|$, the charge transfer resistance $R_{c t}$ and the double layer capacitance $C_{d l}$ are reported in Figure 7 as a function of the Li content $\mathrm{x}$. A crucial difference is seen between the two composition ranges for the cathode impedance $:|\mathrm{Z}|$ slightly decreases with $\mathrm{x}$ between 180 and $140 \Omega$ for $\mathrm{x} \leq 0.6$ but then strongly increases by a factor 2 for $\mathrm{x}>0.6$ and more to reach $475 \Omega$ for $\gamma-\mathrm{LiV}_{2} \mathrm{O}_{5}$ (Figure 7a). As seen from Figure 7b, the charge transfer resistance $\mathrm{R}_{\mathrm{ct}}$ remains constant around $\approx 55 \Omega$ in the first half of the Li insertion process $(0<\mathrm{x} \leq 0.4)$ with an exchange current density of $0.46 \mathrm{~mA} \mathrm{~cm}^{-2}$, in line with usual $\mathrm{j}^{\circ}$ values found for other 
transition metal oxides [20, 25, 41, 42]. This constant $\mathbf{R}_{\mathrm{ct}}$ value corresponds to a biphasic region where $\gamma^{\prime}-\mathrm{V}_{2} \mathrm{O}_{5}$ and $\gamma-\mathrm{Li}_{0.4} \mathrm{~V}_{2} \mathrm{O}_{5}$ coexist [40]. For $\mathrm{x}>0.5$, the kinetics of charge transfer is however progressively slowed with further lithiation, as indicated by the continuous $R_{c t}$ increase to reach $75 \Omega$ for $\gamma-\mathrm{LiV}_{2} \mathrm{O}_{5}\left(\mathrm{j}^{\circ}=0.34 \mathrm{~mA} / \mathrm{cm}^{2}\right)$. The double layer capacitance $\mathrm{C}_{\mathrm{dl}}$ remains stable, around $18 \mu \mathrm{F} \mathrm{cm}^{-2}$ in the first part of the discharge, to reach $24 \mu \mathrm{F} \mathrm{cm}^{-2}$ in the second half (Figure 7c).

These electrochemical results have been interpreted in the light of the structural data recently reported during the electrochemical $\mathrm{Li}$ insertion in $\gamma^{\prime}-\mathrm{V}_{2} \mathrm{O}_{5}$ [40]. It was shown that the discharge-charge profile in the $0<x \leq 1$ composition range corresponds to a two phase behaviour for $0<\mathrm{x}<0.4$ followed by a wide single phase $\gamma-\mathrm{Li}_{\mathrm{x}} \mathrm{V}_{2} \mathrm{O}_{5}$ domain for $0.4 \leq \mathrm{x} \leq 1$. These structural changes are associated to a weak unit cell volume expansion of only $4 \%$. Clearly, the present study evidences a change in the cathode impedance $|Z|$, the charge transfer resistance $\mathrm{R}_{\mathrm{ct}}$ and the double layer capacitance $\mathrm{C}_{\mathrm{dl}}$ in the second half of the discharge, i.e. from $\mathrm{x} \approx 0.5$. This change in the kinetic parameters characterizes the Li enrichment of the $\gamma-\mathrm{Li}_{0.4} \mathrm{~V}_{2} \mathrm{O}_{5}$ phase according to a solid solution behaviour to progressively reach the $\gamma-\mathrm{LiV} \mathrm{V}_{2} \mathrm{O}_{5}$ phase [40]. The $\mathrm{C}_{\mathrm{dl}}$ increase can be explained by the slight volume expansion of the active material of a few percent, leading to a moderate increase in the electrochemical surface area. The significant increase in both the charge transfer resistance and electrode impedance suggests that the growing $\mathrm{V}^{4+} / \mathrm{V}^{5+}$ ratio disadvantages the rate of charge transfer, because of a decrease in the electronic conduction. Such an assumption is supported by the crystallographic data reported for the two types of vanadium environment available in the Lifree $\gamma^{\prime}-\mathrm{V}_{2} \mathrm{O}_{5}$ phase and the lithiated $\gamma-\mathrm{LiV}_{2} \mathrm{O}_{5}$ phase $[39,40]$. Indeed, $\mathrm{V}_{\mathrm{a}} \mathrm{O}_{5}$ and $\mathrm{V}_{\mathrm{b}} \mathrm{O}_{5}$ pyramids volumes are similar in $\gamma^{\prime}-\mathrm{V}_{2} \mathrm{O}_{5}\left(4.461 \AA^{3}\right.$ and $4.531 \AA^{3}$, respectively), due to the presence of $\mathrm{V}^{5+}$ ions in both polyhedra. Conversely, in $\gamma-\mathrm{LiV}_{2} \mathrm{O}_{5}$, different values of respectively $4.675 \AA^{3}$ and $5.114 \AA^{3}$ account for the existence of $\mathrm{V}^{5+}$ ions in $\mathrm{V}_{\mathrm{a}} \mathrm{O}_{5}$ pyramids and $\mathrm{V}^{4+}$ ions in $\mathrm{V}_{\mathrm{b}} \mathrm{O}_{5}$ pyramids. This highly localized electron character highlighted in $\gamma$ $\mathrm{LiV}_{2} \mathrm{O}_{5}$ is well correlated with the highest cathode impedance and charge transfer resistance values observed for the $\mathrm{x}=1$ composition. Then, the upward trend of both parameters with $\mathrm{x}$ suggests a progressive increase in the electron localization with the $\mathrm{V}^{4+} / \mathrm{V}^{5+}$ ratio.

A reliable evaluation of the apparent lithium diffusion coefficient $\mathrm{D}_{\mathrm{Li}}$ has been achieved over the whole $0<x \leq 1$ lithium composition range. In the first part of the discharge $(0<x \leq 0.6)$, 
a Warburg domain can be reliably defined (see inset in Figure 6a). The numerical values of $\mathrm{D}_{\mathrm{Li}}$ have been calculated from the analysis of the Warburg impedance plotted in the complex plane: -Im $Z$ or $\operatorname{Re} Z=A_{w} \omega^{-1 / 2}$, using equation (1) [41]:

$A_{w}$ is the Warburg prefactor, $V_{M}$ is the molar volume of the compound $\left(V_{M}=53.9 \mathrm{~cm}^{3} \cdot \mathrm{mol}^{-1}\right)$, $\mathrm{S}$ is the geometric surface area of the electrode $\left(1 \mathrm{~cm}^{2}\right),(\mathrm{dE} / \mathrm{dx})_{\mathrm{x}}$ is the slope, at fixed $\mathrm{x}$, of the equilibrium potential composition curve (Figure 3).

For $0.6<\mathrm{x} \leq 1, \mathrm{D}_{\mathrm{Li}}$ has been calculated from the limiting low frequency resistance $\mathrm{R}_{\mathrm{L}}$, using equation (2) [41]:

$\mathrm{L}$ is the maximum length of the diffusion pathway, estimated to a few $\mu \mathrm{m}$ from SEM images, i.e, $\mathrm{L} \approx 1.510^{-4} \mathrm{~cm}$. $\mathrm{R}_{\mathrm{L}}$ is graphically determined from the intersection of the low frequency asymptote with the real axis after subtraction of electrolyte and charge transfer resistances (see inset in Figure $6 \mathbf{b}$ ). $\mathrm{R}_{\mathrm{L}}$ values of $24,12,13$ and $8 \Omega$ are found for respectively $\mathrm{x}=0.7$, $0.8,0.9$ and 1 .

The resulting $D_{\mathrm{Li}}$ values in the $0<\mathrm{x} \leq 1$ composition range are plotted in Figure 8. The lowest $\mathrm{D}_{\mathrm{Li}}$ values are found at the beginning of the reaction for $0<\mathrm{x} \leq 0.3$ around $10^{-12} \mathrm{~cm}^{2} \mathrm{~s}^{-}$ 1 , i.e. practically in the $\gamma^{\prime}-\mathrm{V}_{2} \mathrm{O}_{5} / \gamma-\mathrm{Li}_{0.4} \mathrm{~V}_{2} \mathrm{O}_{5}$ biphasic region. Then, as soon as the first member of the monophasic region is formed $(\mathrm{x}=0.4)$, Li transport is significantly promoted with values in the range $10^{-10}-10^{-9} \mathrm{~cm}^{2} \mathrm{~s}^{-1}$ in spite of higher Li contents $(\mathrm{x}=0.4,0.5$ and 0.6$)$. In the second half of the discharge, the disappearance of the Warburg region at the benefit of the quasi-vertical line of the finite diffusion highlights a much faster diffusion kinetics. Assuming a $\mathrm{L}$ value of $\approx 1.5 \mu \mathrm{m}, \mathrm{D}_{\mathrm{Li}}$ is found to still increase from $2.410^{-10}$ to $4.310^{-9} \mathrm{~cm}^{2} \mathrm{~s}^{-1}$ from $\mathrm{x}=$ 0.7 to $\mathrm{x}=1$. The order of magnitude between the two sets of data should be at least of one decade given the comparison of extrapolated limiting frequencies: in the order of $10^{-3} \mathrm{~Hz}$ when $0.1 \leq \mathrm{x} \leq 0.6$ against a few dozen of $\mathrm{mHz}$ when $0.7 \leq \mathrm{x} \leq 1$. $\mathrm{D}_{\mathrm{Li}}$ appears as constant in the biphasic region, i.e. when $\mathrm{x}<0.4$ while lithium ions more rapidly diffuse in the single-phase region $0.4 \leq \mathrm{x} \leq 1$. It is worth noticing the present $\mathrm{D}_{\mathrm{Li}}$ evolution evidenced for the puckered $\gamma^{\prime}-\mathrm{V}_{2} \mathrm{O}_{5}$ host lattice contrasts with the more complex variations of lithium diffusivity reported for the parent $\alpha-\mathrm{V}_{2} \mathrm{O}_{5}$ oxide $[6,19-21,23,24]$. This 
discrepancy can be related to the emergence of successive distorted phases during Li insertion in $\alpha-\mathrm{V}_{2} \mathrm{O}_{5}$ in the same $0<\mathrm{x} \leq 1$ composition range.

The higher Li diffusivity evidenced in the second part of the discharge indicates that the capacity decline observed at higher $\mathrm{C}$ rate (Figure 4) could not be ascribed to diffusional limitations but mainly to large cathode impedance and slowdown in the charge transfer kinetics. Improvement of the rate capability must therefore comprise the optimization of these two parameters. Substitutional or interstitial cation incorporation in $\gamma^{\prime}-\mathrm{V}_{2} \mathrm{O}_{5}$ could be envisioned to enhance the electronic conductivity. Combined with appropriate mastering of the particle size and morphology, such strategies should allow optimizing the charge transfer rate and taking advantage of the high Li mobility highlighted in $\gamma^{\prime}-\mathrm{V}_{2} \mathrm{O}_{5}$.

\section{Conclusion}

The electrochemical properties of the puckered $\gamma^{\prime}-\mathrm{V}_{2} \mathrm{O}_{5}$ polymorph toward Li insertion are reported here in the high voltage window corresponding to the exchange of $1 \mathrm{Li}^{+} / \mathrm{mole}$ of oxide $(4.0 \mathrm{~V}-2.5 \mathrm{~V})$. The corresponding specific capacity of $147 \mathrm{mAh} \mathrm{g}^{-1}$ is interestingly available at a higher working voltage than $\alpha-\mathrm{V}_{2} \mathrm{O}_{5}(+0.2 \mathrm{~V})$. Two well-defined steps at $3.6 \mathrm{~V}$ and $3.5 \mathrm{~V}$ account for the formation of the lithiated $\gamma-\mathrm{LiV}_{2} \mathrm{O}_{5}$ phase. A good cycle life is achieved at $\mathrm{C} / 10$ rate with still $130 \mathrm{mAh} \mathrm{g}^{-1}$ recovered after 50 cycles. In addition, the rate capability is satisfactory with specific capacities of $100 \mathrm{mAh} \mathrm{g}^{-1}$ and $80 \mathrm{mAh} \mathrm{g}^{-1}$ at $\mathrm{C}$ and $2 \mathrm{C}$ rates, respectively. The kinetic parameters for the electrochemical $\mathrm{Li}$ insertion reaction have been investigated using $\mathrm{AC}$ impedance measurements. A reliable determination of the chemical diffusion coefficient is made over the whole $0 \leq \mathrm{x} \leq 1$ lithium composition range, using either the Warburg domain or the limiting resistance. This study highlights the diffusion rate is slower in the first half of the discharge $(x<0.4)$ corresponding to a diphasic region while the solid solution domain $(0.4<\mathrm{x} \leq 1)$ is characterized by higher $\mathrm{D}_{\mathrm{Li}}$ values by one or two orders of magnitude (around $10^{-9} \mathrm{~cm}^{2} \mathrm{~s}^{-1}$ ). In the second part of the discharge, the kinetics of the reaction is however impeded by a slowdown in the electron transfer kinetics, as illustrated by the increase in charge transfer resistance $\mathrm{R}_{\mathrm{ct}}$ and cathode impedance. The highly localized electron character in $\gamma-\mathrm{LiV}_{2} \mathrm{O}_{5}$ accounts probably for the highest cathode impedance and charge transfer resistance values observed for the $\mathrm{x}=1$ composition. The kinetic behaviour revealed in this work for $\gamma^{\prime}-\mathrm{V}_{2} \mathrm{O}_{5}$ differs from that of the unfolded parent $\alpha-\mathrm{V}_{2} \mathrm{O}_{5}$ 
277 oxide showing large and complex $\mathrm{D}_{\mathrm{Li}}$ variations. Such discrepancy originates probably from 278 different structural mechanisms upon lithiation of the two polymorphs, i.e. minimal structural 279 changes involving a large solid solution domain for the puckered-layered $\mathrm{V}_{2} \mathrm{O}_{5}$ polymorph vs. 280 successive phase transitions toward distorted $\varepsilon-$ and $\delta-\mathrm{Li}_{\mathrm{x}} \mathrm{V}_{2} \mathrm{O}_{5}$ for $\alpha-\mathrm{V}_{2} \mathrm{O}_{5}$. Further efforts 281 made in direction of particle size mastering and morphology have already allowed a great 282 enhancement in the rate capability performance. These results will be published very soon. 
286 Figure 1. X-ray diffraction pattern of $\gamma^{\prime}-\mathrm{V}_{2} \mathrm{O}_{5}$. Inset: SEM micrograph of the $\gamma^{\prime}-\mathrm{V}_{2} \mathrm{O}_{5}$ powder 287 Figure 2. Crystal structure of $\gamma^{\prime}-\mathrm{V}_{2} \mathrm{O}_{5}$

288 Figure 3. Discharge curve of $\gamma^{\prime}-\mathrm{V}_{2} \mathrm{O}_{5}$ at low current density (C/100 rate)

289 Figure 4. Discharge-charge curves of $\gamma^{\prime}-\mathrm{V}_{2} \mathrm{O}_{5}$ in the $4.00 \mathrm{~V}-2.50 \mathrm{~V}$ potential range. $\mathrm{C} / 10$ rate

Figure 5. Influence of the $\mathrm{C}$ rate on the discharge-charge profiles of $\gamma^{\prime}-\mathrm{V}_{2} \mathrm{O}_{5}$ (a) Discharge capacity as a function of the $\mathrm{C}$-rate $(\mathrm{b}) . \mathrm{C} / 10-5 \mathrm{C}$ range

Figure 6. AC impedance diagrams for $\gamma-\mathrm{Li}_{\mathrm{x}} \mathrm{V}_{2} \mathrm{O}_{5}$ electrodes (a) $0 \leq \mathrm{x} \leq 0.6$; (b) $0.7 \leq \mathrm{x} \leq 1$

293 Figure 7. Evolution of the cathode impedance $|\mathrm{Z}|$ (a), the charge transfer resistance $\mathrm{R}_{\mathrm{ct}}(\mathrm{b})$ and the double layer capacitance $\mathrm{C}_{\mathrm{dl}}(\mathrm{c})$ in $\gamma-\mathrm{Li}_{\mathrm{x}} \mathrm{V}_{2} \mathrm{O}_{5}(0<\mathrm{x} \leq 1)$.

Figure 8. Evolution of the apparent chemical diffusion coefficient of lithium $\mathrm{D}_{\mathrm{Li}}$ as a function of $\mathrm{x}$ in in $\gamma-\mathrm{Li}_{\mathrm{x}} \mathrm{V}_{2} \mathrm{O}_{5}$. The double dashed line separates the composition domain in which $\mathrm{D}_{\mathrm{Li}}$ has been determined using either eq (1) or eq (2).

298

299

300

301 


\section{References}

[1] M.S. Whittingham, Chem. Rev. 104, 4271 (2004).

[2] D. W. Murphy, P. A. Christian, F. J. Disalvo, J. V. Waszczak, Inorg. Chem. 18, 2800 (1979).

[3] J. P. Pereira-Ramos, R. Messina, C. Piolet, J. Devynck, Electrochim. Acta. 33, 1003 (1988).

[4] C. Delmas, H. Cognac-Auradou, J. M. Cocciantelli, M. Menetrier, J. P. Doumerc, Solid State Ionics 69, 257 (1994).

[5] K. West, B. Zachau-Christiansen, T. Jacobsen, S. Skaarup, Solid State Ionics 76, 15 (1995).

[6] Y. Sato, T. Asada, H. Tokugawa, K. Kobayakawa, J. Power Sources 68, 674 (1997).

[7] P. G. Dickens, S. J. French, A. T. Hight, M. F. Pye, Mater. Res. Bull. 14, 1295 (1979).

[8] J. M. Cocciantelli, J. P. Doumerc, M. Pouchard, M. Broussely, J. Labat, J. Power Sources 34, 103 (1991).

[9] R. Baddour-Hadjean, A. Marzouk, J. P. Pereira-Ramos, J. Raman Spectrosc. 43, 153 (2012).

[10] D. Huo, A. Contreras, B. Laïk, P. Bonnet, K. Guérin, D. Muller-Bouvet, C. CenacMorthe, R. Baddour-Hadjean, J. P. Pereira-Ramos, Electrochim. Acta 245, 350 (2017).

[11] B. Pecquenard, D. Gourier, N. Baffier, Solid State Ionics 78, 287 (1995).

[12] E. Prouzet, C. C. D. Moulin, F. Villain, A. Tranchant,, J. Chem. Soc. Faraday Trans. 92, 103 (1996).

[13] P. Rozier, J. M. Savariault, J. Galy, Solid State Ionics 98, 133 (1997).

[14] P. Rozier, J. M. Savariault, J. Galy, C. Marichal, J. Hirschinger, P. Granger, Eur. J. Solid State Inorg. Chem. 33, 1 (1996).

[15] J. M. Savariault, P. Rozier, Phys. B. 234, 97 (1997).

[16] R. J. Cava, A. Santoro, D. W. Murphy, S. M. Zahurak, R. M. Fleming, P. Marsh, R. S. Roth, J. Solid State Chem. 65, 63 (1986).

[17] H. Katzke, M. Czank, W. Depmeier, S. Van Smaalen, Philos. Mag B-Physics Condens. Matter Stat. Mech. Electron. Opt. Magn. Prop. 75, 757 (1997).

[18] X. Rocquefelte, F. Boucher, P. Gressier, G. Ouvrard, Chem. Mater. 15, 1812 (2003).

[19] J. P. Pereira-Ramos, R. Messina, J. Perichon, Solid State Ionics 40/41, 974 (1990).

[20] J. Farcy, R. Messina, J. Perichon, J. Electrochem. Soc., 137, 1337 (1990).

[21] S. I. Pyun, J. S. Bae, Electrochim. Acta 41, 919 (1996). 
[22] C. Navone, R. Baddour-Hadjean, J. P. Pereira-Ramos, R. Salot, Electrochim. Acta 53, 3329 (2008).

[23] D.Y. Yoo, I. H. Yeo, W. I. Cho, Y. Kang, S. I. Mho, Analytical Sciences 29, 1083 (2013).

[24] Y. Luo, L. R. De Jesus, J. L. Andrews, A. Parija, N. Fleer, D. Juarez Robles, P. P. Mukherjee, S. Banerjee, ACS Appl. Mater. Interfaces 10, 30901 (2018).

[25] D. Huo, B. Laïk, P. Bonnet, K. Guérin, R. Baddour-Hadjean, J. P. Pereira-Ramos, Electrochim. Acta 253, 472 (2017).

[26] A. Parija, D. Prendergast, S. Banerjee, ACS Appl. Mater. Interfaces 9, 23756 (2017).

[27] A. Parija, Y. Liang, J.L. Andrews, L.R. De Jesus, D. Prendergast, S. Banerjee, Chem. Mater. 28, 5611 (2016).

[28] J. M. Cocciantelli, P. Gravereau, J. P. Doumerc, M. Pouchard, P. Hagenmuller, J. Solid State Chem. 93, 497 (1991).

[29] J. M. Cocciantelli, M. Menetrier, C. Delmas, J. P. Doumerc, M. Pouchard, P. Hagenmuller, Solid State Ionics 50, 99 (1992).

[30] J. Barker, M. Y. Saidi, J. L. Swoyer, J. Electrochem. Soc. 150, A1267 (2003).

[31] J. Dai, S. F. Y. Li, Z. Gao, K. S. Siow, Chem. Mater. 11, 3086 (1999).

[32] W. Wang, H. Wang, S. Liu, J. Huang, J. Solid State Electrochem. 16, 2555 (2012).

[33] Y. W. Wang, H. Y. Xu, H. Wang, Y. C. Zhang, Z. Q. Song, H. Yan, C. R. Wan, Solid State Ionics 167, 419 (2004).

[34] N. Li, H, Gong, Y. Qian, Chin. J. Chem. Phys., 26, 597 (2013).

[35] S. Caes, J. C. Arrebola, N. Krins, P. Eloy, E. M. Gaigneaux, C. Henrist, R. Cloots, B. Vertruyen, J. Mater. Chem. A., 2, 5809 (2014).

[36] M. Safrany Renard, N. Emery, R. Baddour-Hadjean, J.P. Pereira-Ramos, Electrochim. Acta 252C, 4 (2017).

[37] M. Safrany Renard, N. Emery, E. M. Roginskii, R. Baddour-Hadjean, J. P. PereiraRamos, J. Solid State Chem. 254, 62 (2017).

[38] R. Baddour-Hadjean, L.T. Huynh, N. Emery, J.P. Pereira-Ramos , Electrochim. Acta 270, 129 (2018).

[39] N. Emery, R. Baddour-Hadjean, D. Batyrbekuly, B. Laïk, Z. Bakenov, J. P. PereiraRamos, Chem. Mater. 30, 5305 (2018).

[40] R. Baddour-Hadjean, M. Safrany Renard, J.P. Pereira-Ramos, Acta Mater. 165, 183 (2019).

[41] C. Ho, I. D. Raistrick, R.A. Huggins, J. Electrochem. Soc., 127, 343 (1980). 
370 [42] B. Garcia, J. Farcy, J. P. Pereira-Ramos, N. Baffier, J. Electrochem. Soc., 144, 1179 371 (1997).

372

373

374

375

376

377

378

379

380 
Figures

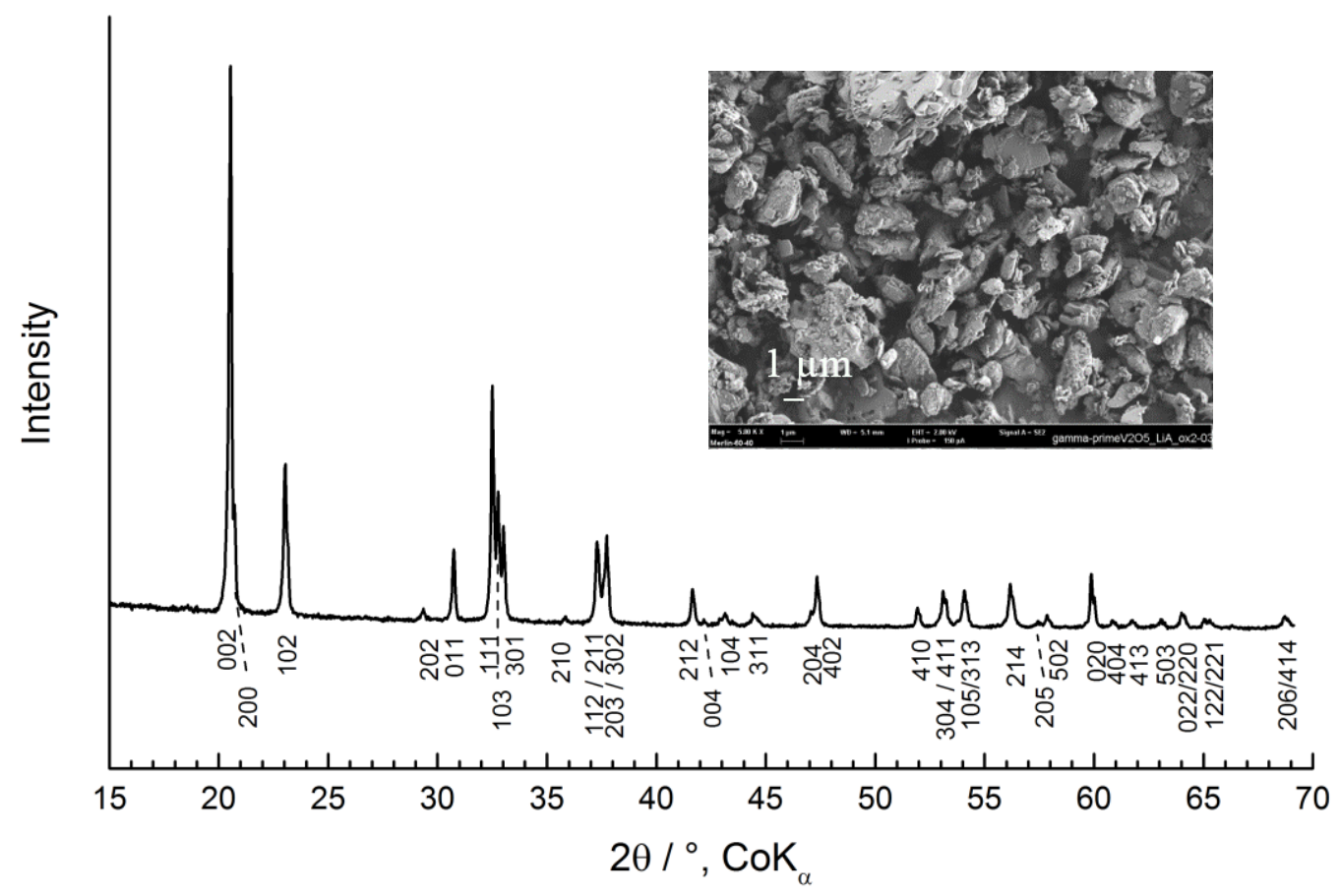

Figure 1. X-ray diffraction pattern of $\gamma^{\prime}-\mathrm{V}_{2} \mathrm{O}_{5}$. Inset: SEM micrograph of the $\gamma^{\prime}-\mathrm{V}_{2} \mathrm{O}_{5}$ powder 


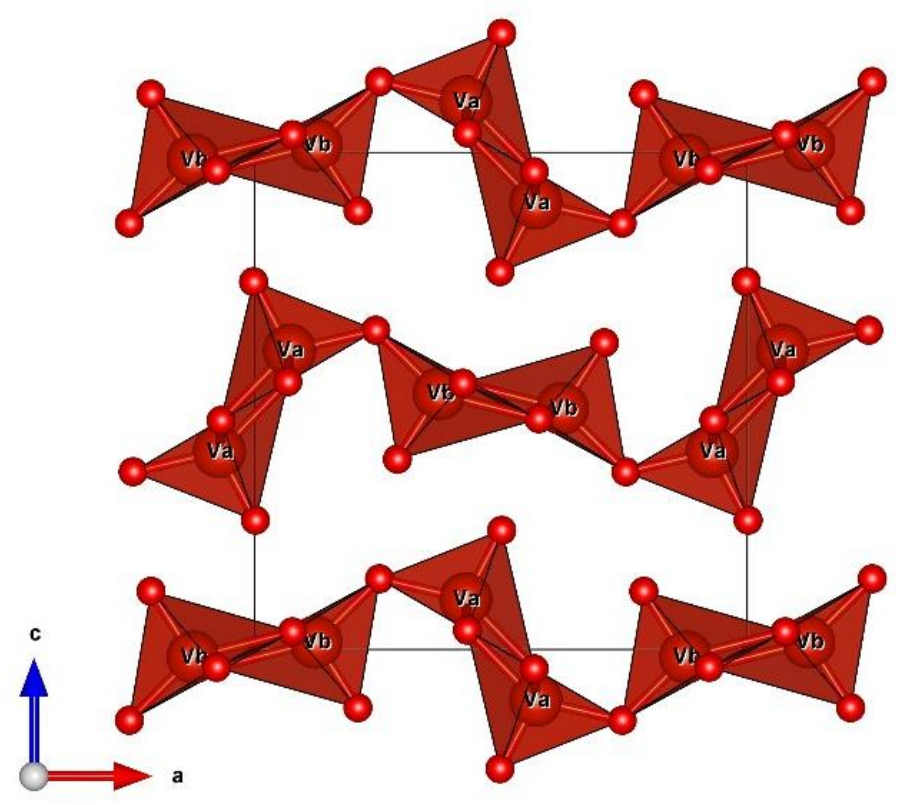

Figure 2. Crystal structure of $\gamma^{\prime}-\mathrm{V}_{2} \mathrm{O}_{5}$ 


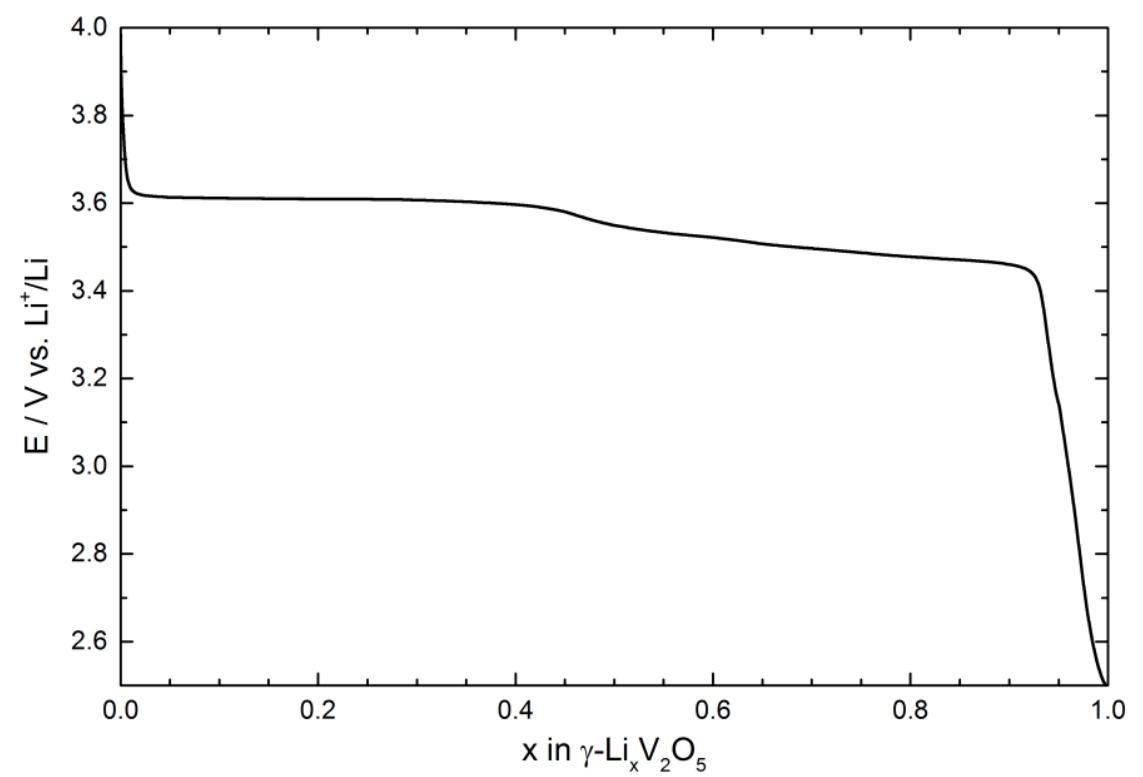

Figure 3. Discharge curve of $\gamma^{\prime}-\mathrm{V}_{2} \mathrm{O}_{5}$ at low current density (C/100 rate) 


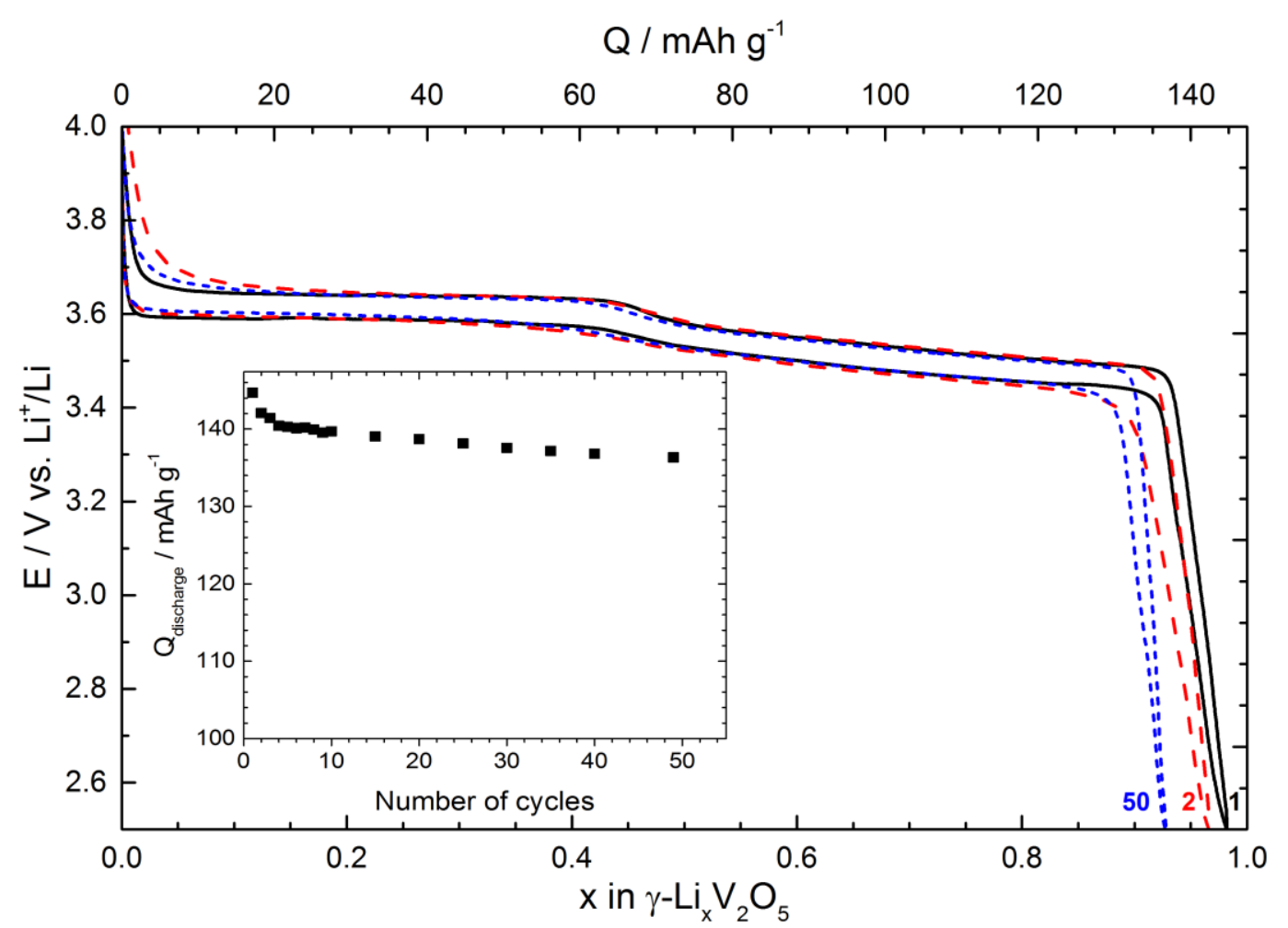

Figure 4. Discharge-charge curves of $\gamma^{\prime}-\mathrm{V}_{2} \mathrm{O}_{5}$ in the $4.00 \mathrm{~V}-2.50 \mathrm{~V}$ potential range. $\mathrm{C} / 10$ rate 

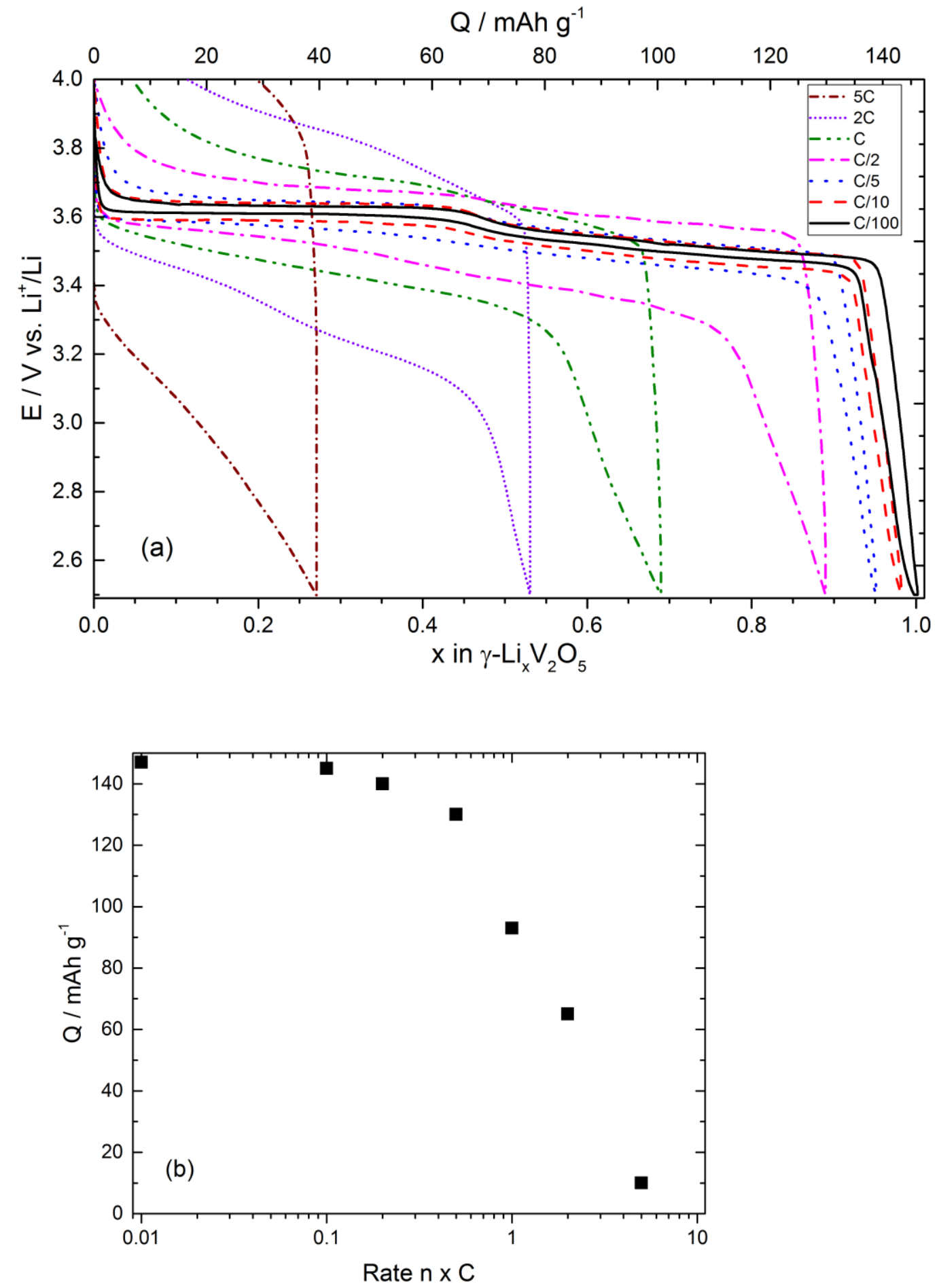

Figure 5. Influence of the $\mathrm{C}$ rate on the discharge-charge profiles of $\gamma^{\prime}-\mathrm{V}_{2} \mathrm{O}_{5}$ (a) Discharge capacity as a function of the $\mathrm{C}$-rate $(\mathrm{b}) . \mathrm{C} / 10-5 \mathrm{C}$ range 

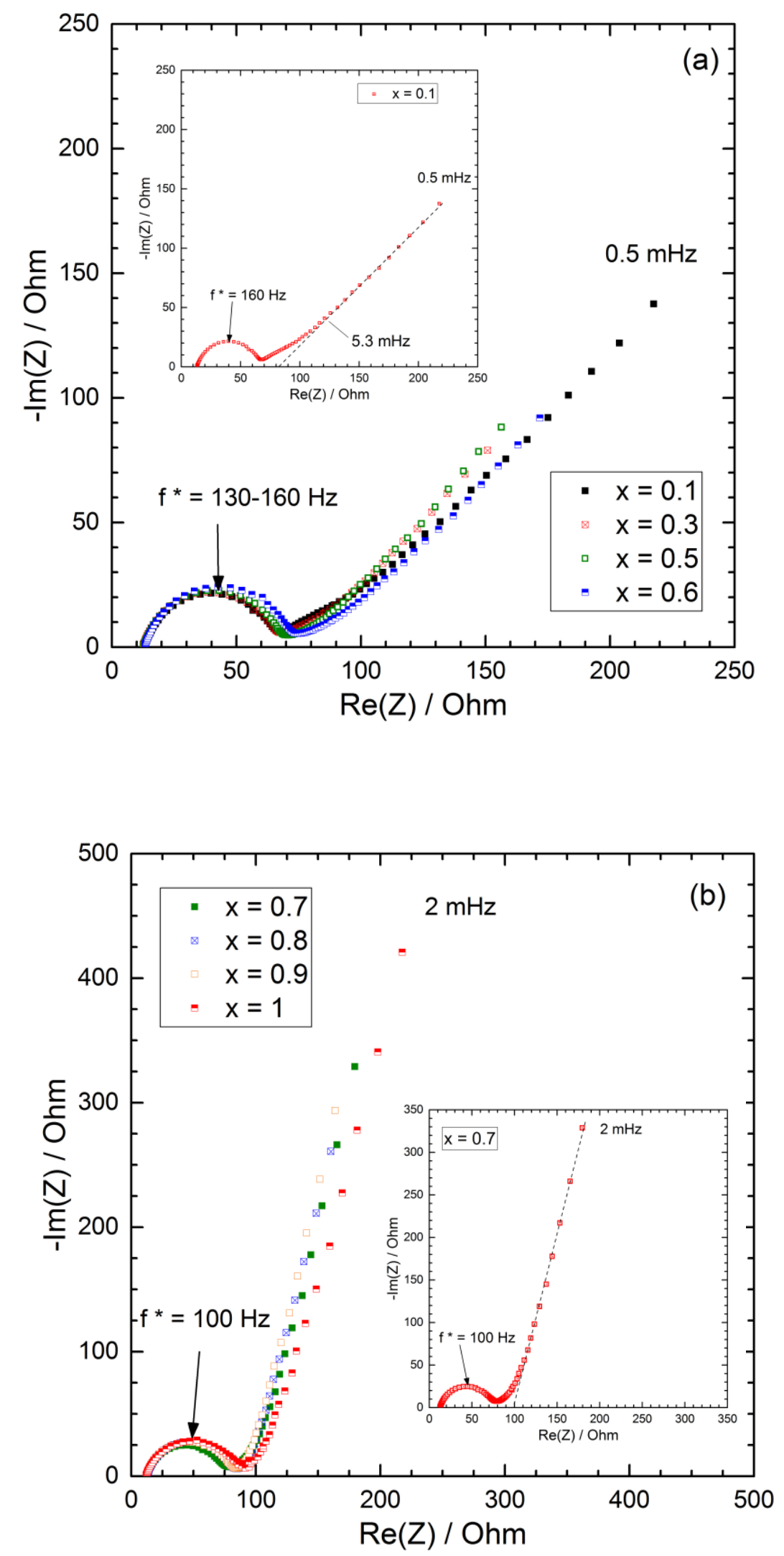

Figure 6. $\mathrm{AC}$ impedance diagrams for $\gamma-\mathrm{Li}_{\mathrm{x}} \mathrm{V}_{2} \mathrm{O}_{5}$ electrodes (a) $0 \leq \mathrm{x} \leq 0.6$; (b) $0.7 \leq \mathrm{x} \leq 1$ 

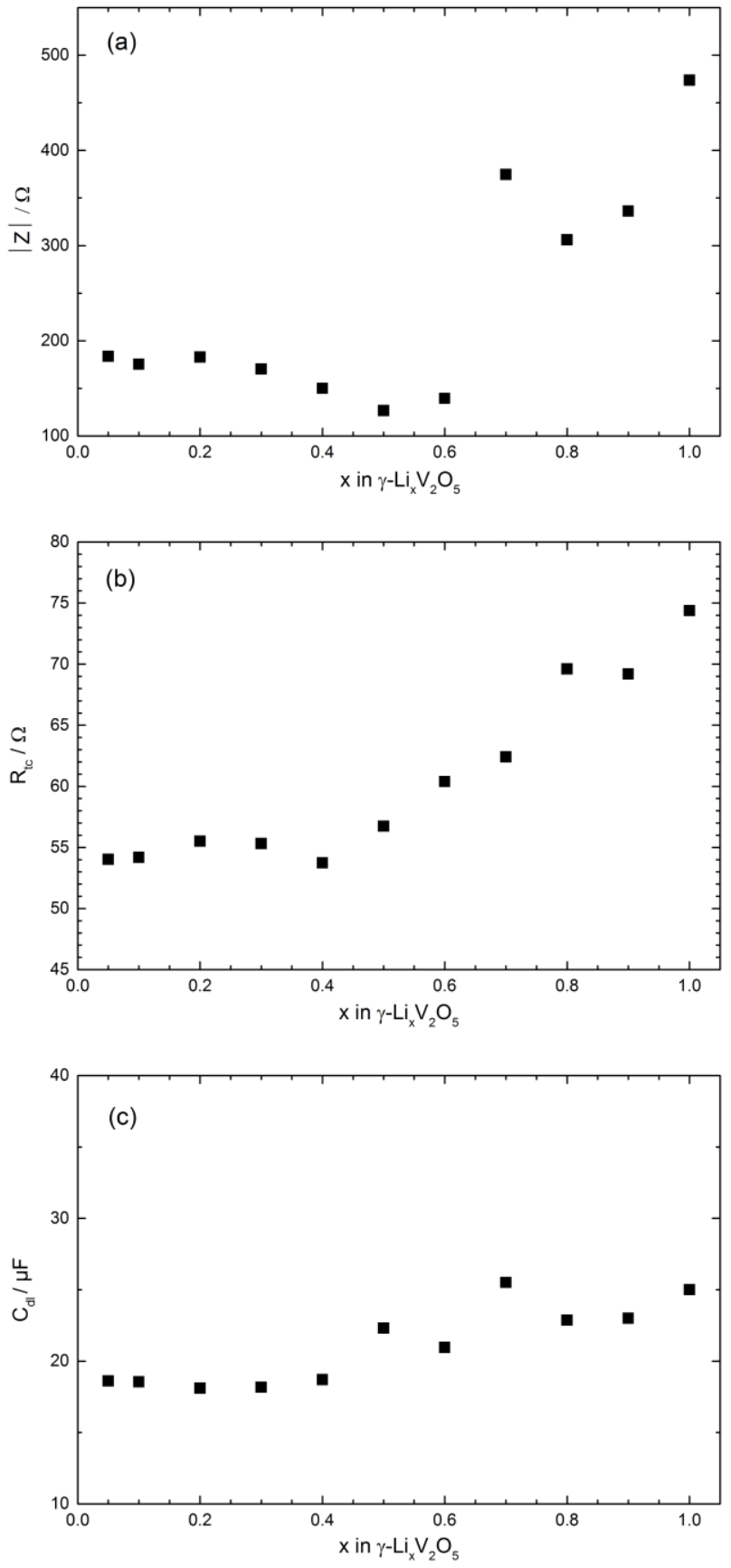

Figure 7. Evolution of the cathode impedance $|\mathrm{Z}|$ (a), the charge transfer resistance $\mathrm{R}_{\mathrm{ct}}(\mathrm{b})$ and the double layer capacitance $\mathrm{C}_{\mathrm{dl}}(\mathrm{c})$ in $\gamma-\mathrm{Li}_{\mathrm{x}} \mathrm{V}_{2} \mathrm{O}_{5}(0<\mathrm{x} \leq 1)$. 


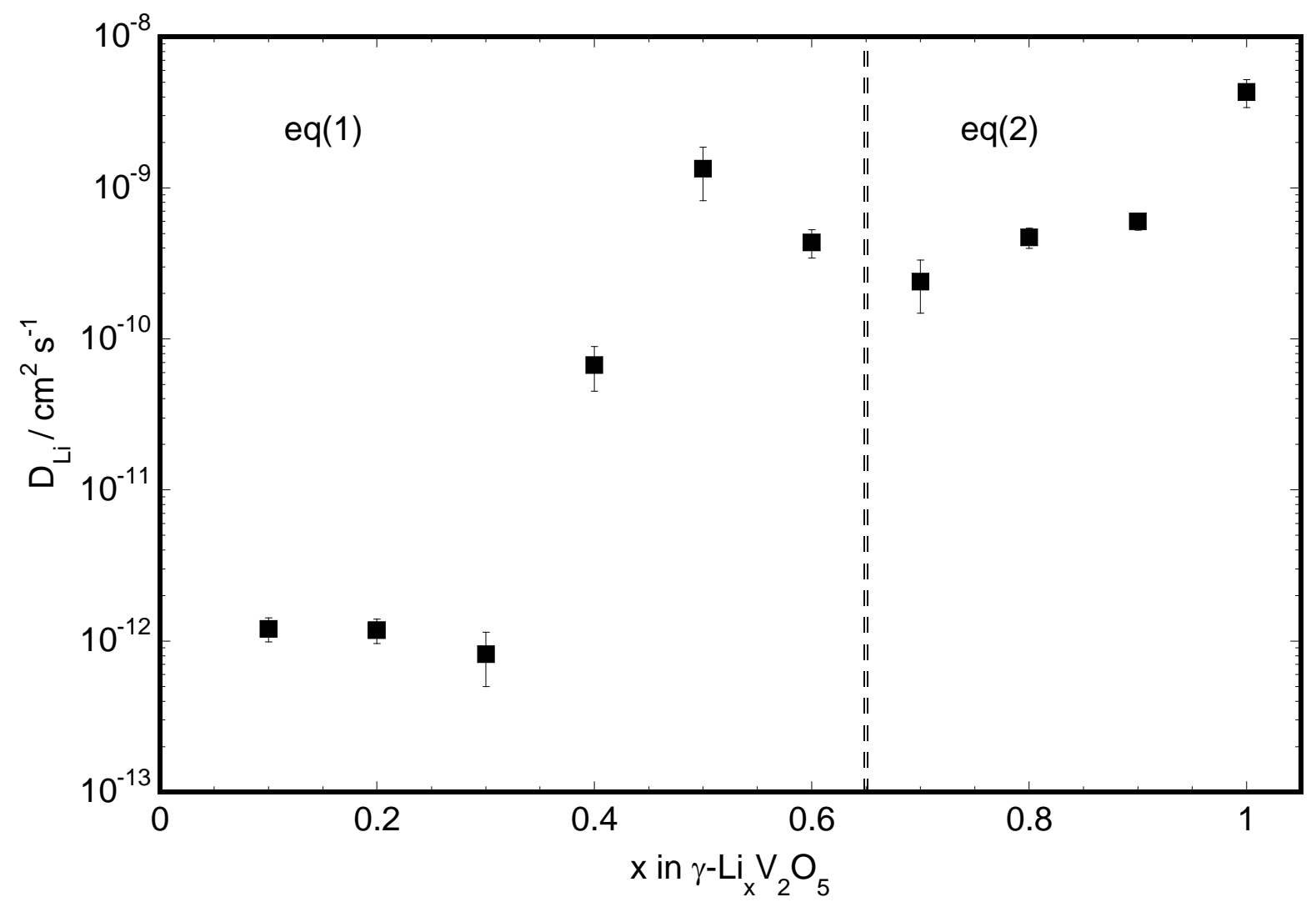

Figure 8. Evolution of the apparent chemical diffusion coefficient of lithium $\mathrm{D}_{\mathrm{Li}}$ as a function of $\mathrm{x}$ in in $\gamma-\mathrm{Li}_{\mathrm{x}} \mathrm{V}_{2} \mathrm{O}_{5}$. The double dashed line separates the composition domain in which $\mathrm{D}_{\mathrm{Li}}$ has been determined using either eq (1) or eq (2). 